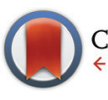

CrossMark click for updates

Cite this: Org. Biomol. Chem., 2015, 13, 4231

Received 4th February 2015,

Accepted 26th February 2015

DOI: $10.1039 / c 50 b 00245 a$

www.rsc.org/obc

\title{
Flow synthesis of ethyl isocyanoacetate enabling the telescoped synthesis of 1,2,4-triazoles and pyrrolo-[1,2-c]pyrimidines $\uparrow$
}

\begin{abstract}
Marcus Baumann, ${ }^{a}$ Antonio M. Rodriguez Garcia ${ }^{a, b}$ and lan R. Baxendale*a
The efficient flow synthesis of important heterocyclic building blocks based on the 1,2,4-triazole and pyrrolo[1,2-c]pyrimidine scaffold has been achieved. Crucially, a telescoped continuous flow process was developed based on the reaction of $\mathrm{N}$-formylglycine with triphosgene to deliver a stream of ethyl isocyanoacetate in situ, which subsequently yielded the desired heterocyclic entities in a telescoped reaction. Additionally, the functionalisation of the pyrrolo[1,2-c]pyrimidine core via subsequent $S_{E} A r$ reactions was studied revealing insight into a 'halogen dance' phenomenon associated with these medicinally relevant architectures.
\end{abstract}

\section{Introduction}

The efficient preparation of novel heterocyclic building blocks functionalised with suitable derivatisation sites is of paramount importance to the successful discovery of new bioactive molecules. ${ }^{1}$ Certainly the most effective pharmaceutical and agrochemical strategy for the generation of propriety leads is through screening of diverse core structures, which upon strategic functionalisation engenders desirable physiological properties and yields focused libraries of advanced drug-like structures. Consequently, the conformational presentation displayed by the core template impacts strongly on the available binding and contact points that can be interacted upon within the biological environment. It is therefore not surprising that most of today's top-selling drugs contain at least one heterocyclic core often acting as its pharmacophore. ${ }^{2}$ In order to efficiently access new chemical scaffolds medicinal chemists have been increasingly exploiting enabling technologies to allow access to novel chemical space. ${ }^{3}$ Amongst these technologies flow chemistry approaches have gained widespread acceptance as a powerful means to overcome limitations regarding scale-up, reproducibility, safety and accessible chemical space with numerous publications detailing the results of such studies. ${ }^{4}$

\footnotetext{
${ }^{a}$ Department of Chemistry, Durham University, South Road, Durham, DH1 3LE, UK. E-mail: i.r.baxendale@durham.ac.uk

${ }^{b}$ Universidad de Castilla-La Mancha, Departamento de Química Orgánica, Facultad de Ciencias y Tecnologías Quimicas, Avd. Camilo José Cela, 10, 13071 Ciudad Real, Spain

$\dagger$ Electronic supplementary information (ESI) available. CCDC 1039437, 1039438 1039439, 1039440 and 1039441. For ESI and crystallographic data in CIF or other electronic format see DOI: 10.1039/c5ob00245a
}

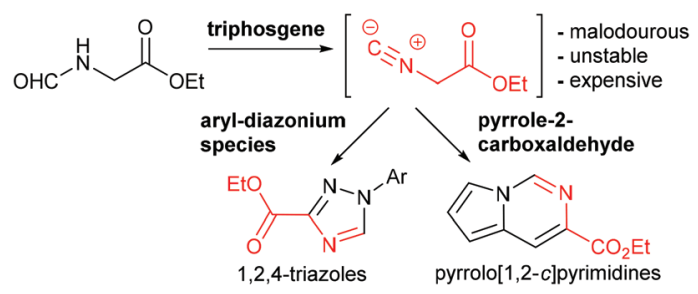

Scheme 1 Multi-step flow approach towards valuable heterocyclic scaffolds.

One particular area where flow chemistry has led to significantly improved safety profiles compared to traditional batch synthesis is the in situ generation and subsequent use of highly reactive, yet hazardous species. Examples include, but are not limited to, the generation and use of ozone, ${ }^{5}$ azides, ${ }^{6}$ diazonium species, ${ }^{7}$ or elemental fluorine ${ }^{8}$ as well as cryogenic $^{9}$ or high temperature ${ }^{10}$ reactions.

In this paper we wish to disclose our latest results towards the flow synthesis of valuable heterocyclic architectures such as 1,2,4-triazoles and pyrrolo[1,2-c]pyrimidines based on the in situ generation of ethyl isocyanoacetate through the dehydration of $\mathrm{N}$-formylglycine using reactive triphosgene (Scheme 1).

\section{Results and discussion}

\section{Synthesis of ethyl isocyanoacetate in flow}

Ethyl isocyanoacetate (3) is a commercially available high boiling liquid characterised by its pungent odour as well as its sensitivity towards light and moisture. Despite this it is fre- 

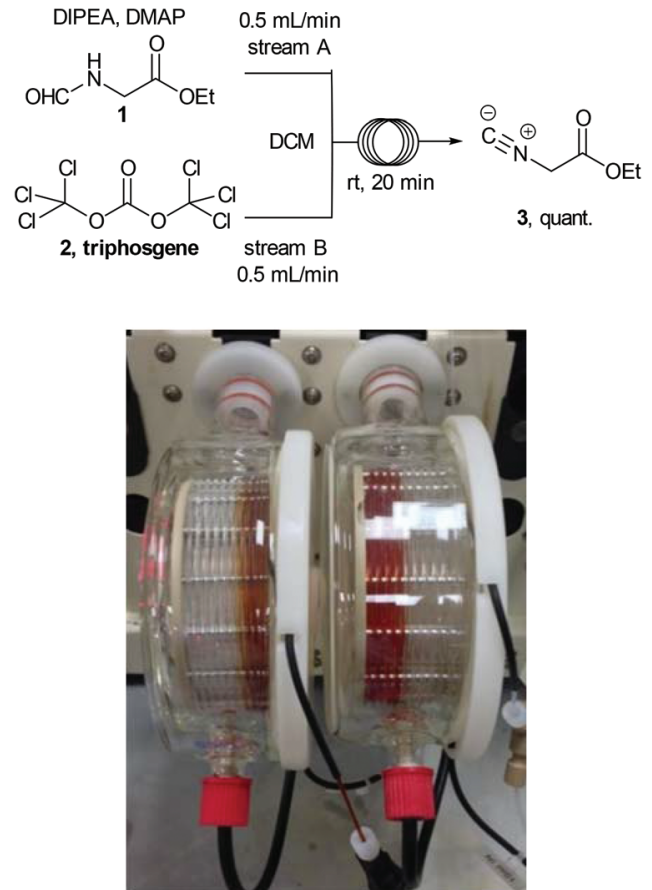

Scheme 2 Flow synthesis of ethyl isocyanoacetate (Reactor flow pathway left to right).

quently used as a key building block in multicomponent reactions and heterocycle synthesis. ${ }^{11}$ Because of these features we decided to develop a convenient in situ flow synthesis of ethyl isocyanoacetate starting from readily available $\mathrm{N}$-formylglycine (1). ${ }^{12}$ As the dehydrating agent we choose triphosgene (2), a commercially available crystalline solid. ${ }^{13}$ This material is not only easier to handle than many other dehydrating agents (e.g. $\mathrm{COCl}_{2}, \mathrm{POCl}_{3}, \mathrm{SOCl}_{2}$ etc.), but also comprises three equivalents of active dehydrating agent per molecule. Furthermore, only $\mathrm{HCl}$ and $\mathrm{CO}_{2}$ are generated as by-products through its use. In an initial study we used a commercially available R2+ Vapourtec flow reactor which was configured to mix two reagent streams via a T-piece: stream $\boldsymbol{A}$ contained $\mathrm{N}$-formylglycine (DCM, 0.25 M, 1.0 equiv.), DIPEA (2 equiv.) and DMAP (0.3 equiv.) and stream $\boldsymbol{B}$ contained triphosgene (DCM, $0.0875 \mathrm{M}$, 0.35 equiv.). Using ${ }^{1} \mathrm{H}$-NMR analysis of aliquots of the product stream it was quickly established that the desired ethyl isocyanoacetate forms almost quantitatively at room temperature within a $20 \mathrm{~min}$ residence time (Scheme 2).

\section{Synthesis of 1,2,4-triazoles in flow}

Having developed an efficient protocol for the synthesis of ethyl isocyanoacetate in flow, we next turned our attention to its reaction with various aryl diazonium species, also prepared in situ, to furnish a convergent synthesis of 1,2,4-triazoles. ${ }^{14}$

To facilitate the reaction, four stock solutions (solutions 1-4) were prepared, along with a small collection of aniline starting materials (solution 5). To perform the multi-step flow sequence an integrated flow reactor configured as shown in
Scheme 3 was constructed. This comprised a Uniqsis FlowSyn with an ALF delivery and control system, a Vapourtec R2+/R4 unit, two auxiliary Knauer K100 HPLC pumps and two Polar bear plus flow reactors (see ESI $\dagger$ for additional details). Using this setup a continuous flow stream of intermediate 3 was prepared as described (see above) and was united with a solution containing the corresponding diazonium coupling partner 6 as a convergent assembly process.

The diazonium component $\mathbf{6}$ was readily prepared from the precursor aniline or its mono-hydrochloride salts (in MeCN) by treatment with tert-butyl nitrite at ambient temperature. ${ }^{15}$ For the subsequent cycloaddition reaction the two flow streams containing $\mathbf{3}$ and $\mathbf{6}$ were combined and then in succession diluted with a stream of pure ethanol and treated with an aqueous feed of potassium carbonate (5 equiv.). A static mixer was placed in-line to thoroughly blend the flow stream before it passed into a heated reaction coil maintained at $75^{\circ} \mathrm{C}$. The reactor output was collected and worked up by evaporation of the solvent followed by neutralisation with dilute hydrochloric acid and partitioning into ethyl acetate. The products were isolated in high yield and purity after solvent evaporation and trituration of the crude product with a mixture of diethyl etherethanol 15:1. Pleasingly the above flow protocol proved general and was applied to the synthesis of a small selection of 1,2,4-triazole products (7a-h) (Fig. 1).

\section{Derivatisation of 1,2,4-triazoles}

In order to briefly evaluate the feasibility of these $[1,2,4]$-triazoles $(\mathbf{7 a}-\mathbf{h})$ to serve as building blocks towards future research efforts we decided to specifically study the functionalisation of the 5-position of the heterocyclic core. To this end regioselective bromination was affected by treating $7 \mathbf{h}$ with a mixture of $\mathrm{NaH}$ and NBS in dry $\mathrm{THF}^{16}$ (Scheme 4). Pleasingly, after $10 \mathrm{~h}$ reaction time, complete consumption of the starting material and clean formation of the desired product $\mathbf{8}$ was observed. After purification $\mathbf{8}$ was subjected to a small number of Suzuki cross coupling reactions in order to synthesise 9a-e. ${ }^{17}$ Although this reaction required prolonged reaction times at elevated temperatures $\left(8-10 \mathrm{~h}\right.$ at $\left.120{ }^{\circ} \mathrm{C}\right)$ the desired Suzuki cross coupling products were formed chemoselectively and isolated in reasonable yield allowing further efforts to be directed towards the diversification of these scaffolds.

\section{Synthesis of pyrrolo[1,2-c]pyrimidines in flow}

After accomplishing a successful multi-step flow synthesis of various 1,2,4-triazoles we decided to diversify the protocol towards the synthesis of another underexploited scaffold - the pyrrolo[1,2-c]pyrimidine. This structure has shown value for example as the core structure of various nicotinic acetylcholine receptor agonists developed to treat CNS disorders ${ }^{18}$ and can be prepared by reacting ethyl isocyanoacetate with readily available pyrrole-2-carboxaldehyde. ${ }^{19}$ After a short optimisation study we found that treatment of a flow stream of ethyl isocyanoacetate with a secondary stream containing pyrrole-2carboxaldehyde (10, $0.25 \mathrm{M}, 1.0$ equiv.) and piperidine 


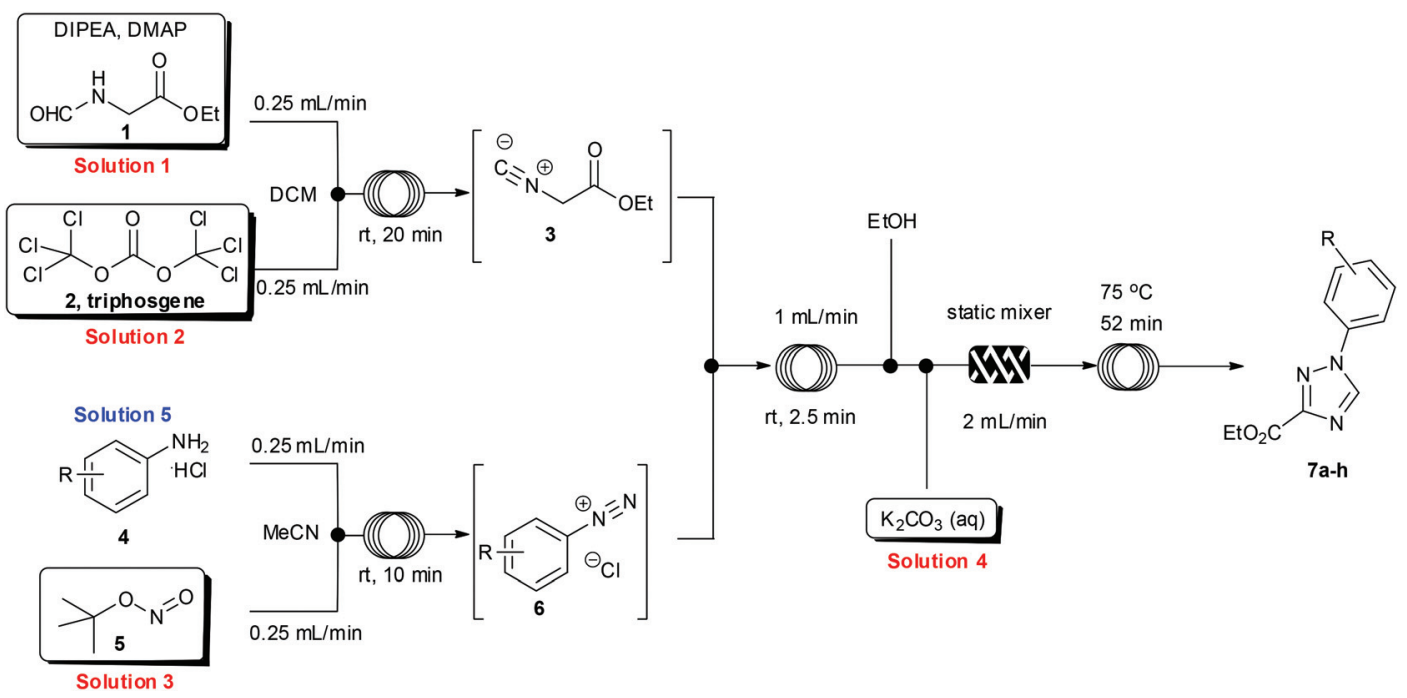

Scheme 3 Multi-step flow approach towards 1,2,4-triazoles.<smiles>CCOC(=O)c1ncn(-c2cccc(F)c2)n1</smiles><smiles>CCOC(=O)c1ncn(-c2cccc(C)c2)n1</smiles><smiles>CCOC(=O)c1ncn(-c2cccc(OC)c2)n1</smiles><smiles>CCOC(=O)c1ncn(-c2cccc(Cl)c2)n1</smiles>

$7 g$<smiles>CCOC(=O)c1ncn(-c2cccc(C(F)(F)F)c2)n1</smiles><smiles>CCOC(=O)c1ncn(-c2ccc(Br)cc2)n1</smiles><smiles>C#CC(=O)c1ncn(-c2ccc(Cl)cc2)n1</smiles>

$7 \mathrm{~h}$
$7 f$

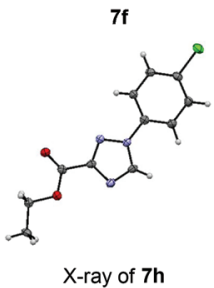

X-ray of $7 \mathrm{~h}$

Fig. 1 Representative [1,2,4]-triazoles prepared in flow.

(6 equiv.) in DCM afforded the desired pyrrolo[1,2-c]pyrimidine structure 11 after passing through a flow coil maintained at slightly elevated temperature $\left(85^{\circ} \mathrm{C}, 26 \mathrm{~min}\right.$ residence time, Scheme 5; Fig. 2).

In order to avoid any issues of precipitate formation within the flow system (i.e. piperidine-HCl salts) a working concentration of $0.25 \mathrm{M}$ was targeted resulting in a theoretical throughput of $5.71 \mathrm{~g} \mathrm{~h}^{-1}$. The desired pyrrolo[1,2-c]pyrimidine product could be isolated in $85 \%$ yield and high purity $(>95 \%$ by ${ }^{1} \mathrm{H}-\mathrm{NMR}$ ) as a beige solid after extraction and evaporation of the volatiles. This crude material was of sufficient quality to be used in further reactions however an analytical sample was
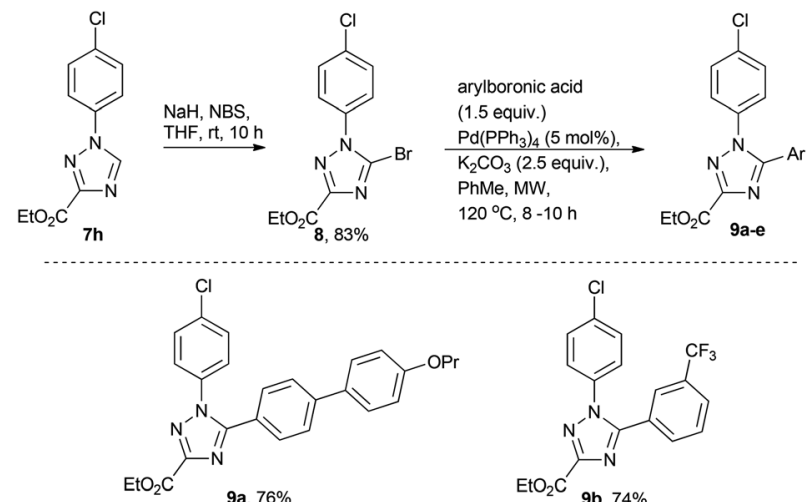<smiles>CCOC(=O)c1nc(-c2ccccc2C(C)C)n(-c2ccc(Cl)cc2)n1</smiles><smiles>COc1ncccc1-c1nc(C(=O)OC(C)(C)C)nn1-c1ccc(Cl)cc1</smiles><smiles>CCOC(=O)c1nc(-c2cccc(C(F)(F)F)c2)n(-c2ccc(Cl)cc2)n1</smiles><smiles>CCOC(=O)c1nc(-c2ccc(OC)c(OC)c2)n(-c2ccc(Cl)cc2)n1</smiles>

Scheme 4 Functionalization study of triazole $7 \mathrm{~h}$.

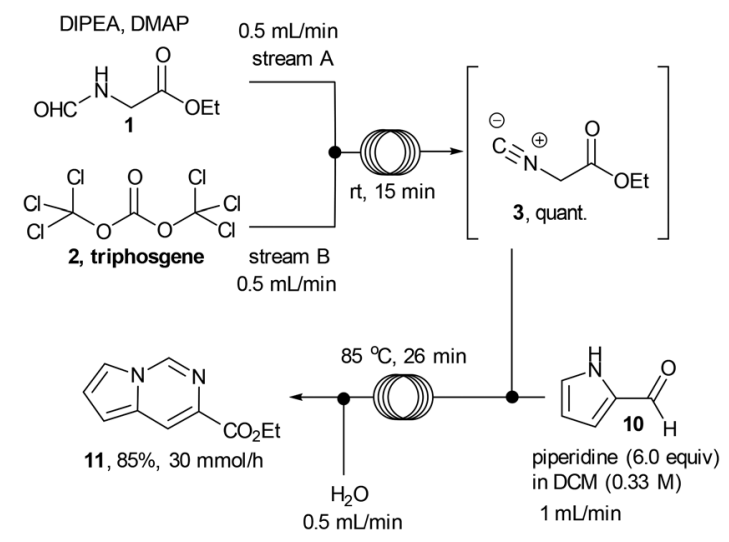

Scheme 5 Multi-step flow approach towards pyrrolo[1,2-c]pyrimidine. 


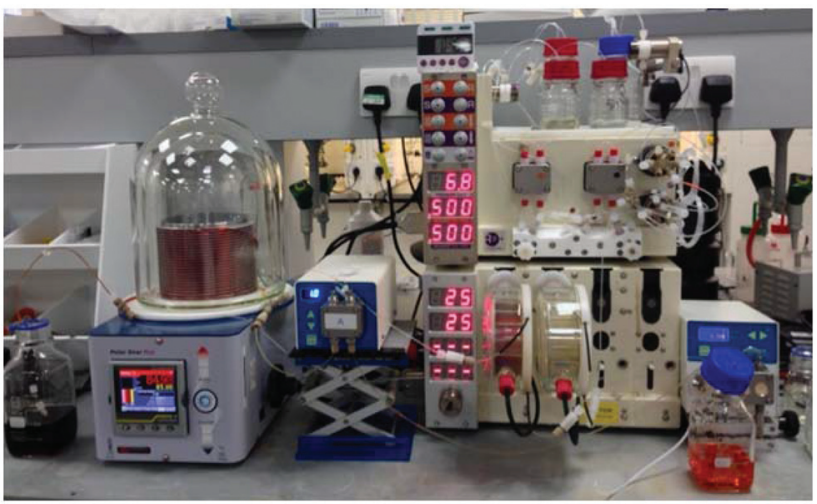

Fig. 2 Flow reactor used for the synthesis of pyrrolo[1,2-c]pyrimidine.

further purified by column chromatography to furnish a yellow solid $(78 \%)$. The reactor could be run under semi-continuous operation delivering $\sim 30 \mathrm{~g}$ over the course of a standard working day $(8 \mathrm{~h})$ including start-up/shut down and cleaning of the system.

Having established convenient access to multigram quantities of this pyrrolo[1,2-c]pyrimidine core (11) we decided to evaluate its functionalisation via electrophilic aromatic substitution reactions. Specifically we intended to establish whether this scaffold could be decorated in a regioselective manner allowing access to versatile architectures for future synthesis programmes. We therefore performed a number of Density Functional Theory (DFT) calculations to compare the intermediates originating from addition to the most likely $\mathrm{C} 7$ and C5 positions of the pyrrole subunit (Scheme 6, Table 1). The geometries of the species were optimised with the $6-311++\mathrm{G}$ (2df,2pd) basis set (for iodine the cc-pVTZ-PP basis set ${ }^{20}$ with the Stuttgarts pseudopotential ${ }^{21}$ was used) employing Truhlar functionals, M06-2X, ${ }^{22}$ which have been shown to successfully describe the thermochemistry, kinetics, and noncovalent interactions of such systems. The computational calculations were performed using Gaussian 09 program suite ${ }^{23}$ frequency analysis was also performed to confirm the nature of the station-

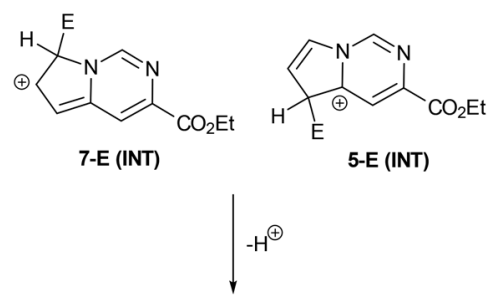<smiles>CCOc1cc2ccc(C)n2cn1</smiles>

7-E (PROD)

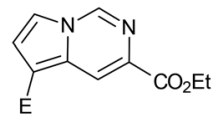

5-E (PROD)
Scheme 6 General schematic of the DFT calculations performed on the electrophilic attack on the pyrrolopyrimidine moiety.
Table 1 Collected Gibbs free energies on the structures

\begin{tabular}{lllr}
\hline & & \multicolumn{2}{l}{$\Delta G\left(\mathrm{Kcal} \mathrm{mol}^{-1}\right) \mathrm{M} 06-2 \mathrm{x} /$} \\
\cline { 3 - 3 } Entry & Compound & $\mathrm{INT}^{a}$ & PROD $^{a}$ \\
\cline { 3 - 4 } 1 & $5-311++\mathrm{G}(2 \mathrm{df}, 2 \mathrm{pd})$ & -1.92 \\
2 & $7-\mathrm{Cl}$ & 3.23 & $\mathbf{0 . 0 0}$ \\
3 & $5-\mathrm{Br}$ & $\mathbf{0 . 0 0}$ & -0.86 \\
4 & 7-Br & 1.62 & $\mathbf{0 . 0 0}$ \\
5 & $5-\mathrm{I}$ & $\mathbf{0 . 0 0}$ & -1.39 \\
6 & 7-I & 0.76 & $\mathbf{0 . 0 0}$
\end{tabular}

${ }^{a}$ The energies are all reported relative to the 7-halo compounds which were the thermodynamic control compounds.

ary points and to obtain zero-point energies (ZPEs). Solvent effects on molecular geometries and energies were estimated by means of Polarization Continuum Models $(\mathrm{PCM})^{24}$ with DCM as the solvent.

The data correlated in Table 1, implies a distinct kinetic preference for reaction at the $\mathrm{C} 7$ over $\mathrm{C} 5$ position due to enhanced delocalisation into the adjacent ring, however the most stable products are those with substitution at C5. Further DFT studies, also confirmed the nucleophilic character of the specified $\mathrm{C} 5$ and $\mathrm{C} 7$ positions of the pyrrolo[1,2-c]pyrimidine (Fig. 3). We were therefore confident that a regioselective functionalisation of the pyrrolopyrimidine could be achieved.

We subsequently prepared a number of pyrrolo[ $[1,2-c]$ pyrimidine derivatives (12a-i) confirming that the most reactive site was indeed the $\mathrm{C} 7$ position of the pyrrole moiety followed by the C5 position. This analysis was largely enabled by single crystal X-ray diffraction experiments as ${ }^{1} \mathrm{H}$ - and ${ }^{13} \mathrm{C}-\mathrm{NMR}$ experiments were not always conclusive (Scheme 7).

Whilst this strategy allowed for the efficient and regioselective monofunctionalisation at $\mathrm{C} 7$ via halogenation $(\mathrm{Cl}, \mathrm{Br}$. I), formylation and acetylation reactions, it was noted that the subsequent introduction of a second electrophilic substituent did not always furnish the predicted product.

The nitration or bromination of the chlorinated pyrrolo[1,2-c]pyrimidine intermediate did yield the expected reaction products

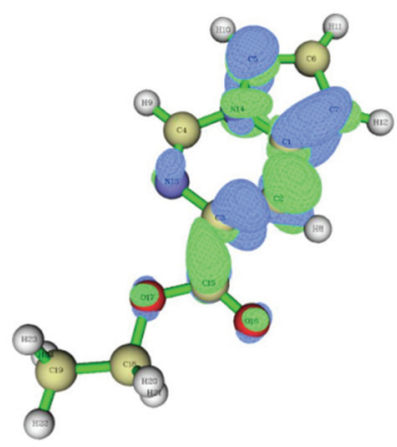

Fig. 3 Dual descriptor Fukui function of pyrrolo[1,2-c]pyrimidine (11). (green electrophilic regions; blue nucleophilic regions). 


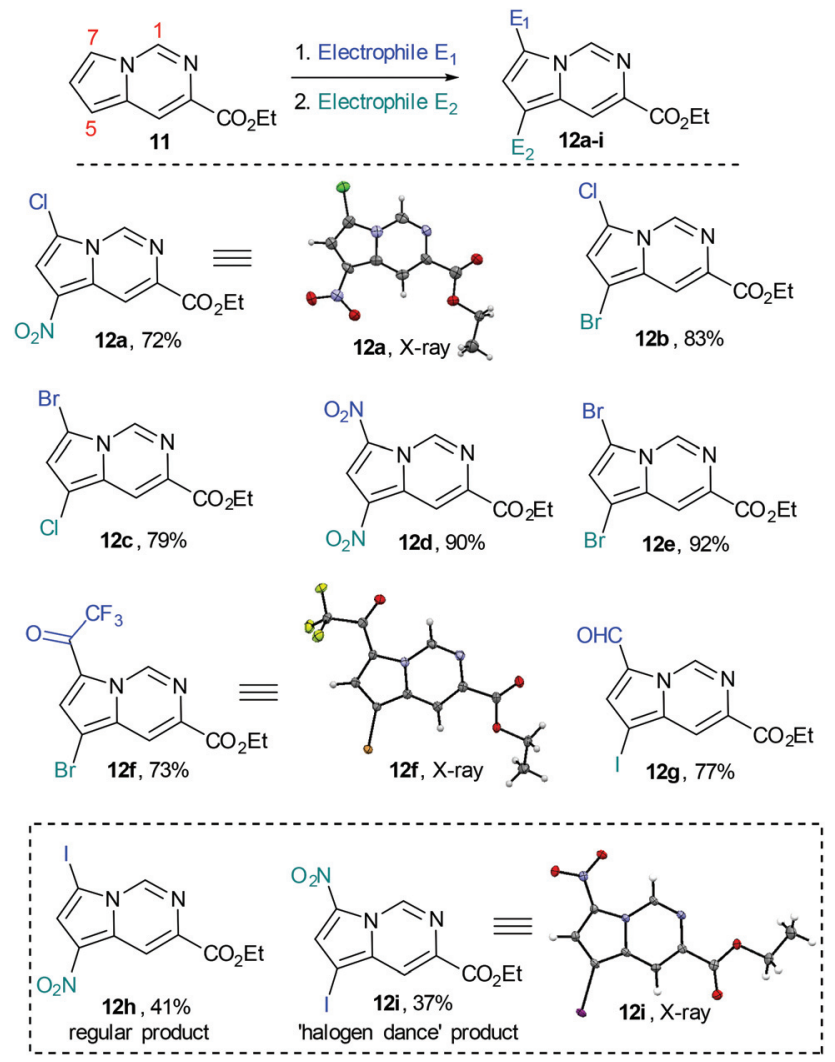

Scheme 7 Functionalization of the pyrrolo[1,2-c]pyrimidine core by $\mathrm{S}_{\mathrm{E}} \mathrm{Ar}$ reactions (overall isolated yields for 2 steps).

12a and 12b. However, preparation of the dihalo-structure 12c was only possible when halogenating (use of NBS or NCS) under neutral conditions. Conducting the chlorination step in the presence of $\mathrm{HCl}$ or for prolonged reaction times (i.e. $>10 \mathrm{~h}$ ) resulted in the formation of a mixture of $\mathbf{1 2 b}$ and $\mathbf{1 2 c}$.

Additionally, when attempting nitration of substrate 8 it was noted that a mixture of two mono-nitrated products as well as the di-nitrated scaffold 12d formed very rapidly. Furthermore, attempted nitration of the 7-mono-iodinated pyrrolo[1,2-c]pyrimidine core yielded a mixture of nitrated products $(\mathbf{1 2 h}, \mathbf{1 2 \mathbf { i }})$ that after longer reaction time $(12 \mathrm{~h})$ would also generate small quantities $(\sim 15 \%)$ of the previously prepared di-nitrated product 12d. As the identity of $12 \mathbf{i}$ had been confirmed by single crystal X-ray diffraction experiments, we suggest the occurrence of a 'halogen dance' phenomenon in cases where brominated or iodinated monofunctionalisation products are subjected to a second $\mathrm{S}_{\mathrm{E}} \mathrm{Ar}$ reaction under strongly acidic conditions. We thus propose that under acidic conditions the second electrophile is again first introduced at C7 generating a tetrahedral intermediate $\mathbf{1 3 b}$ (Scheme 8). This structure can then undergo a [1,3]-shift in which the most weakly bound halogen migrates to the 5-position of the pyrrolo $[1,2-c]$ pyrimidine scaffold (i.e. 13c) thus resembling other 'halogen dance' phenomena reported in the literature. ${ }^{25}$ Overall, the strategic use of this rearrangement could lead to
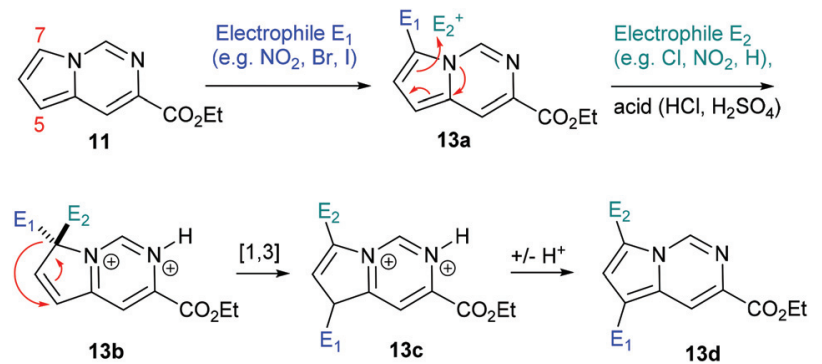

Scheme 8 Proposed mechanism for 'halogen dance' under acidic conditions.

otherwise difficult to access structures and thus opens avenues towards specifically functionalised pyrrolo[1,2-c]pyrimidine scaffolds. Further research is now required to fully evaluate and develop these initial findings.

\section{Conclusions}

In conclusion, we have successfully developed a valuable flow protocol for the synthesis of ethyl isocyanoacetate via dehydration of $N$-formylglycine using triphosgene. The versatility of generating this isocyanide building block in situ was further exploited by multi-step sequences towards various 1,2,4-triazoles as well as the pyrrolo[1,2-c]pyrimidine scaffold, whose further functionalisation by means of $S_{E} A r$ reactions has been demonstrated. These studies have also allowed insights in the occurrence of halogen dance phenomena during the elaboration of the pyrrolo[1,2-c]pyrimidine scaffold. We believe that this study demonstrates the benefits of modern flow techniques in the generation and use of hazardous, yet versatile intermediates towards medicinally relevant structures.

\section{Experimental section}

\section{General experimental section}

${ }^{1} \mathrm{H}-\mathrm{NMR}$ spectra were recorded on either Bruker Avance-400, Varian VNMRS-600 or Varian VNMRS-700 instruments and are reported relative to residual solvent: $\mathrm{CHCl}_{3}(\delta 7.26 \mathrm{ppm})$ or DMSO ( $\delta 2.50 \mathrm{ppm}) .{ }^{13} \mathrm{C}-\mathrm{NMR}$ spectra were recorded on the same instruments and are reported relative to $\mathrm{CHCl}_{3}$ ( $\delta 77.16 \mathrm{ppm})$ or DMSO ( $\delta 39.52 \mathrm{ppm})$. Data for ${ }^{1} \mathrm{H}-\mathrm{NMR}$ are reported as follows: chemical shift $(\delta / \mathrm{ppm})$ (integration, multiplicity, coupling constant $(\mathrm{Hz})$ ). Multiplicities are reported as follows: $\mathrm{s}=$ singlet, $\mathrm{d}=$ doublet, $\mathrm{t}=$ triplet, $\mathrm{q}=$ quartet, $\mathrm{p}=$ pentet, $\mathrm{m}=$ multiplet, br. $\mathrm{s}=$ broad singlet, app $=$ apparent. Data for ${ }^{13} \mathrm{C}-\mathrm{NMR}$ are reported in terms of chemical shift $(\delta / \mathrm{ppm})$ and multiplicity $\left(\mathrm{C}, \mathrm{CH}, \mathrm{CH}_{2}\right.$ or $\left.\mathrm{CH}_{3}\right)$. Data for ${ }^{19} \mathrm{~F}-\mathrm{NMR}$ were recorded on the above instruments at a frequency of $376 \mathrm{MHz}$ using $\mathrm{CFCl}_{3}$ as external standard. DEPT-135, COSY, HSQC, HMBC and NOESY experiments were used in the structural assignment. IR spectra were obtained by use of a Perkin Elmer RX1 spectrometer (neat, ATR sampling) 
with the intensities of the characteristic signals being reported as weak (w, $<20 \%$ of tallest signal), medium (m, 21-70\% of tallest signal) or strong ( $\mathrm{s},>71 \%$ of tallest signal). Low and high resolution mass spectrometry was performed using the indicated techniques on either Waters LCT Premier XE or Waters TQD instruments equipped with Acquity UPLC and a lock-mass electrospray ion source. For accurate mass measurements the deviation from the calculated formula is reported in ppm. Melting points were recorded on an Optimelt automated melting point system with a heating rate of $1{ }^{\circ} \mathrm{C} \mathrm{min}^{-1}$ and are uncorrected.

Single crystal X-ray data were collected at $120.0 \mathrm{~K}$ on a Bruker SMART 6000 (sealed tube, graphite monochromator) (compounds $\mathbf{7 h}$ and SI12f') and Bruker D8 Venture (Photon $100 \mathrm{CMOS}$ detector, I $\mu \mathrm{S}$ microsource, focusing mirrors) (compounds 12a, 12f and 12i) diffractometers $(\lambda \mathrm{MoK} \alpha, \lambda=$ $0.71073 \AA$ ) equipped with Cryostream (Oxford Cryosystems) open flow nitrogen cryostates. The structures were solved by direct methods and refined by full-matrix least squares on $F^{2}$ for all data using SHELX $^{26}$ and OLEX2 ${ }^{27}$ software. All nonhydrogen atoms were refined with anisotropic displacement parameters, the $\mathrm{H}$-atoms in the structures $12 \mathrm{a}, \mathbf{1 2 f}$ and $12 \mathbf{i}$ were placed in calculated positions and refined in "riding" mode. The $\mathrm{H}$ atoms in the other structures were found in the difference Fourier maps and refined isotropically. Crystallographic data and parameters of the refinement are given in Table 1 (ESI $\dagger$ ). Crystallographic data for the structures have been deposited with the Cambridge Crystallographic Data Centre as supplementary publication CCDC-1039437-1039441.

Ethyl 1-(3-chloro-4-fluorophenyl)-1H-1,2,4-triazole-3-carboxylate, 7a. 71\%: Mp 186.3-187.9 ${ }^{\circ} \mathrm{C}$ (decomposed). Compound description: tan solid. ${ }^{\mathbf{1}} \mathbf{H}$ NMR (400 MHz, DMSO- $\boldsymbol{d}_{\mathbf{6}}$ ) $\delta 9.46$ (s, $1 \mathrm{H}), 8.23(\mathrm{dd}, J=6.4,2.7 \mathrm{~Hz}, 1 \mathrm{H}), 7.95$ (ddd, $J=9.0,4.2,2.7$ $\mathrm{Hz}, 1 \mathrm{H}), 7.69$ (t, $J=9.0 \mathrm{~Hz}, 1 \mathrm{H}), 4.39$ (q, $J=7.1 \mathrm{~Hz}, 2 \mathrm{H}), 1.34(\mathrm{t}$, $J=7.1 \mathrm{~Hz}, 3 \mathrm{H}) .{ }^{13} \mathrm{C}$ NMR (101 MHz, DMSO-d $) \delta 159.6(\mathrm{C})$, $157.3(\mathrm{~d}, J=248.6 \mathrm{~Hz}, \mathrm{CF}), 155.2(\mathrm{C}), 145.0(\mathrm{CH}), 133.8$ (d, $J=$ $3.4 \mathrm{~Hz}, \mathrm{C}), 122.9(\mathrm{CH}), 121.5(\mathrm{~d}, J=8.0 \mathrm{~Hz}, \mathrm{CH}), 121.2(\mathrm{~d}, J=$ $19.0 \mathrm{~Hz}, \mathrm{C}), 118.6$ (d, $J=22.7 \mathrm{~Hz}, \mathrm{CH}), 61.9\left(\mathrm{CH}_{2}\right), 14.5\left(\mathrm{CH}_{3}\right)$. ${ }^{19}$ F NMR (376 MHz, DMSO- $d_{6}$ ) $\delta-116.21$ (s). IR (neat): $\nu 3116.9(\mathrm{~m}), 1721.4(\mathrm{~s}), 1511.9(\mathrm{~m}), 1493.3(\mathrm{~s}), 1451.0(\mathrm{~s})$, $1339.7(\mathrm{~m}), 1252.7$ (s), 1202.1 (s), 1089.1 (s), $1051.9(\mathrm{~m})$, 996.6 (s), 849.9 (s), 828.2 (s), 718.9 (s), 667.6 (s), 639.4 (s) $\mathrm{cm}^{-1}$. LC-MS (ESI): 292.1 (M + Na); HRMS (ESI): calculated for $\mathrm{C}_{11} \mathrm{H}_{10} \mathrm{~N}_{3} \mathrm{O}_{2} \mathrm{ClF} 270.0446$, found $270.0443(\mathrm{M}+\mathrm{H}, \Delta=$ $-0.3 \mathrm{ppm})$.

Ethyl 1-( $\boldsymbol{m}$-tolyl)-1H-1,2,4-triazole-3-carboxylate, $7 \mathrm{~b} .68 \%$ : Mp 80.2-81.5 ${ }^{\circ} \mathrm{C}$. Compound description: brown powder. ${ }^{1} \mathbf{H}$ NMR (400 MHz, DMSO-d ) $\delta 9.43(\mathrm{~s}, 1 \mathrm{H}), 7.74$ (dt, $J=1.6,0.8$ $\mathrm{Hz}, 1 \mathrm{H}), 7.69$ (d, $J=7.8 \mathrm{~Hz}, 1 \mathrm{H}), 7.47$ (t, $J=7.8 \mathrm{~Hz}, 1 \mathrm{H}), 7.29$ $(\mathrm{d}, J=7.8 \mathrm{~Hz}, 1 \mathrm{H}), 4.38(\mathrm{q}, J=7.1 \mathrm{~Hz}, 2 \mathrm{H}), 3.36(\mathrm{~s}, 1 \mathrm{H}), 1.34(\mathrm{t}$, $J=7.1 \mathrm{~Hz}, 3 \mathrm{H}) .{ }^{13} \mathrm{C}$ NMR (101 MHz, DMSO-d $\left.\mathbf{6}\right) \delta 159.8$ (C), 155.0 (C), $144.4(\mathrm{CH}), 140.1$ (C), 136.7 (C), $130.1(\mathrm{CH}), 129.7$ $(\mathrm{CH}), 120.8(\mathrm{CH}), 117.4(\mathrm{CH}), 61.8\left(\mathrm{CH}_{2}\right), 21.3\left(\mathrm{CH}_{3}\right), 14.6$ $\left(\mathrm{CH}_{3}\right)$. IR (neat): $3109.9(\mathrm{w}), 1715.6(\mathrm{~s}), 1497.7(\mathrm{~m}), 1448.3(\mathrm{~s})$, 1255.8 (s), 1194.4 (s), 1081.8 (s), 1015.9 (s), 886.1 (m), 848.6 (m), 792.5 (s), 669.4 (s) $\mathrm{cm}^{-1}$. LC-MS (ESI): 254.1 (M + Na);
HRMS (ESI): calculated for $\mathrm{C}_{12} \mathrm{H}_{14} \mathrm{~N}_{3} \mathrm{O}_{2}$ 232.1086, found 232.1084 ( $\mathrm{M}+\mathrm{H}, \Delta=-0.2 \mathrm{ppm})$.

Ethyl 1-(3-methoxyphenyl))-1H-1,2,4-triazole-3-carboxylate, 7c. 53\%: Mp $97.4{ }^{\circ} \mathrm{C}$ (decomposed). Compound description: dark brown solid. ${ }^{1} \mathbf{H}$ NMR (400 MHz, DMSO- $\left.\boldsymbol{d}_{\mathbf{6}}\right) \delta 9.47(\mathrm{~s}, 1 \mathrm{H})$, $7.60-7.38$ (m, 3H), 7.06 (ddd, $J=8.0,2.6,1.9 \mathrm{~Hz}, 1 \mathrm{H}), 4.38$ (q, $J=7.1 \mathrm{~Hz}, 2 \mathrm{H}), 3.86(\mathrm{~s}, 3 \mathrm{H}), 1.34(\mathrm{t}, J=7.1 \mathrm{~Hz}, 3 \mathrm{H}) .{ }^{13} \mathbf{C} \mathbf{N M R}$ (101 MHz, DMSO-d f $\delta 160.7$ (C), 159.7 (C), 155.0 (C), 144.6 $(\mathrm{CH}), 137.8(\mathrm{C}), 131.3(\mathrm{CH}), 114.9(\mathrm{CH}), 112.4(\mathrm{CH}), 106.0(\mathrm{CH})$, $61.8\left(\mathrm{CH}_{2}\right), 56.1\left(\mathrm{CH}_{3}\right), 14.6\left(\mathrm{CH}_{3}\right)$. IR (neat): $3106.8(\mathrm{w}), 1730.3$ (s), $1607.5(\mathrm{~m}), 1504.9$ (s), 1469.9 (s), 1281.3 (s), 1240.8 (s), 1193.7 (s), 1174.4 (s), 1029.4 (s), 992.2 (s), 882.3 (s), 772.0 (s), $669.4(\mathrm{~s}) \mathrm{cm}^{-1}$. LC-MS (ESI): 270.1 (M + Na); HRMS (ESI): calculated for $\mathrm{C}_{12} \mathrm{H}_{14} \mathrm{~N}_{3} \mathrm{O}_{3} 248.1035$, found $248.1035(\mathrm{M}+\mathrm{H}$, $\Delta=0.0 \mathrm{ppm})$.

Ethyl 1-(3-fluorophenyl))-1H-1,2,4-triazole-3-carboxylate, 7d. 62\%: Mp $214.3{ }^{\circ} \mathrm{C}$ (decomposed). Compound description: pale tan solid. ${ }^{1} \mathbf{H}$ NMR (400 MHz, DMSO- $\left.\boldsymbol{d}_{\mathbf{6}}\right) \delta 9.50(\mathrm{~s}, 1 \mathrm{H})$, $7.84(\mathrm{dt}, J=10.0,2.3 \mathrm{~Hz}, 1 \mathrm{H}), 7.79$ (ddd, $J=8.0,2.3,0.9 \mathrm{~Hz}$, $1 \mathrm{H}), 7.65(\mathrm{td}, J=8.3,6.2 \mathrm{~Hz}, 1 \mathrm{H}), 7.36(\mathrm{tdd}, J=8.4,2.6,0.9 \mathrm{~Hz}$, $1 \mathrm{H}), 4.39$ (q, $J=7.1 \mathrm{~Hz}, 2 \mathrm{H}), 1.34(\mathrm{t}, J=7.1 \mathrm{~Hz}, 3 \mathrm{H}) .{ }^{13} \mathbf{C} \mathbf{N M R}$ (101 MHz, DMSO-d $\left.\boldsymbol{d}_{6}\right) \delta 162.8$ (d, $\left.J=245.2 \mathrm{~Hz}, \mathrm{CF}\right), 159.6$ (C), 155.2 (C), 144.9 (CH), 138.0 (d, $J=10.6 \mathrm{~Hz}, \mathrm{C}), 132.3$ (d, $J=9.2$ $\mathrm{Hz}, \mathrm{CH}), 116.4$ (d, $J=3.1 \mathrm{~Hz}, \mathrm{CH}), 115.9$ (d, $J=21.1 \mathrm{~Hz}, \mathrm{CH}$ ), $108.0(\mathrm{~d}, J=26.8 \mathrm{~Hz}, \mathrm{CH}), 61.9\left(\mathrm{CH}_{2}\right), 14.5\left(\mathrm{CH}_{3}\right) .{ }^{19} \mathbf{F}$ NMR (376 MHz, DMSO- $\boldsymbol{d}_{6}$ ) $\delta-110.60$ (s). IR (neat): $3102.2(\mathrm{w})$, 1719.8 (s), 1606.1 (s), 1496.3 (s), 1449.2 (s), 1341.6 (m), 1260.4 (s), $1199.4(\mathrm{~s}), 1004.4(\mathrm{~m}), 862.5(\mathrm{~s}), 783.3(\mathrm{~s}), 667.9(\mathrm{~s}) \mathrm{cm}^{-1}$. LC-MS (ESI): 258.1 ( $\mathrm{M}+\mathrm{Na}$ ); HRMS (ESI): calculated for $\mathrm{C}_{11} \mathrm{H}_{11} \mathrm{~N}_{3} \mathrm{O}_{2} \mathrm{~F} 236.0835$, found $236.0835(\mathrm{M}+\mathrm{H}, \Delta=0.0 \mathrm{ppm})$.

Ethyl 1-(3-(trifluoromethyl)phenyl))-1H-1,2,4-triazole-3-carboxylate, 7e. 55\%: Mp 129.3-130.4 ${ }^{\circ} \mathrm{C}$. Compound description: orange powder. ${ }^{1} \mathbf{H}$ NMR (400 MHz, DMSO-d $\boldsymbol{d}_{\mathbf{6}} \delta 9.61(\mathrm{~s}, 1 \mathrm{H})$, 8.30 (br s, $1 \mathrm{H}), 8.28-8.20(\mathrm{~m}, 1 \mathrm{H}), 7.92-7.80(\mathrm{~m}, 2 \mathrm{H}), 4.40$ (q, $J=7.1 \mathrm{~Hz}, 2 \mathrm{H}), 1.35$ (t, $J=7.1 \mathrm{~Hz}, 3 \mathrm{H}) .{ }^{13} \mathrm{C}$ NMR (101 MHz, DMSO-d $\boldsymbol{d}_{\mathbf{6}} \delta 159.6(\mathrm{C}), 155.3(\mathrm{C}), 145.1(\mathrm{CH}), 137.3(\mathrm{C}), 131.8$ (CH), 130.94 (q, $J=32.5 \mathrm{~Hz}, \mathrm{C}), 125.7$ (q, $J=3.7 \mathrm{~Hz}, \mathrm{CH}), 124.4$ $(\mathrm{CH}), 124.0$ (q, $\left.J=273.6 \mathrm{~Hz}, \mathrm{CF}_{3}\right), 117.14(\mathrm{q}, J=4.0 \mathrm{~Hz}, \mathrm{CH})$, $61.9\left(\mathrm{CH}_{2}\right), 14.5\left(\mathrm{CH}_{3}\right) .{ }^{19}$ F NMR (376 MHz, DMSO-d $\left.\boldsymbol{d}_{6}\right) \delta-61.2$ (s). IR (neat): $3107.7(\mathrm{w}), 1719.8(\mathrm{~m}), 1450.6(\mathrm{~s}), 1316.3(\mathrm{~s})$, 1255.2 (s), 1163.7 (s), 1116.5 (s), 1081.5 (s), 995.1 (m), 902.9 (m), $807.4(\mathrm{~s}), 698.8(\mathrm{~s}), 668.4(\mathrm{~s}) \mathrm{cm}^{-1}$. LC-MS (ESI): 308.1 $\left(\mathrm{M}+\mathrm{Na}\right.$ ); HRMS (ESI): calculated for $\mathrm{C}_{12} \mathrm{H}_{11} \mathrm{~N}_{3} \mathrm{O}_{2} \mathrm{~F}_{3}$ 286.0803, found 286.0795 ( $\mathrm{M}+\mathrm{H}, \Delta=-2.8 \mathrm{ppm})$.

Ethyl 1-(4-bromophenyl))-1H-1,2,4-triazole-3-carboxylate, 7f. 69\%: Mp 152.4-143.8 ${ }^{\circ} \mathrm{C}$. Compound description: white crystalline solid. ${ }^{1} \mathbf{H}$ NMR (400 MHz, DMSO-d $\left.\boldsymbol{d}_{\mathbf{6}}\right) \delta 9.48(\mathrm{~s}, 1 \mathrm{H})$, $7.89(\mathrm{~d}, J=8.9 \mathrm{~Hz}, 2 \mathrm{H}), 7.82(\mathrm{~d}, J=8.9 \mathrm{~Hz}, 2 \mathrm{H}), 4.38$ (q, $J=$ $7.1 \mathrm{~Hz}, 2 \mathrm{H}), 1.34(\mathrm{t}, J=7.1 \mathrm{~Hz}, 3 \mathrm{H}) .{ }^{13} \mathrm{C}$ NMR (101 MHz, DMSO-d D $\delta 159.6(\mathrm{C}), 155.2(\mathrm{C}), 144.7(\mathrm{CH}), 136.0(\mathrm{C}), 133.2$ (2CH), $122.4(2 \mathrm{CH}), 121.8(\mathrm{C}), 61.9\left(\mathrm{CH}_{2}\right), 14.6\left(\mathrm{CH}_{3}\right)$. IR (neat): $3133.7(\mathrm{w}), 1718.4(\mathrm{~s}), 1483.9(\mathrm{~s}), 1451.2(\mathrm{~s}), 1338.4(\mathrm{~m})$, 1257.5 (s), 1203.3 (s), 1067.0 (s), 1029.4 (m), 979.8 (s), 826.9 (s), 668.3 (s) $\mathrm{cm}^{-1}$. LC-MS (ESI): 318.0 (M + Na); HRMS (ESI): calculated for $\mathrm{C}_{11} \mathrm{H}_{11} \mathrm{~N}_{3} \mathrm{O}_{2} \mathrm{Br}$ 296.0035, found $296.0036(\mathrm{M}+\mathrm{H}$, $\Delta=+0.1 \mathrm{ppm})$. 
Ethyl 1-(3-chlorophenyl))-1H-1,2,4-triazole-3-carboxylate, 7g. 68\%: Mp 114.6-115.5 ${ }^{\circ} \mathrm{C}$. Compound description: orange powder. ${ }^{1} \mathbf{H}$ NMR (400 MHz, DMSO- $\left.\boldsymbol{d}_{\mathbf{6}}\right) \delta 9.51(\mathrm{~s}, 1 \mathrm{H}), 8.06(\mathrm{t}$, $J=2.0 \mathrm{~Hz}, 1 \mathrm{H}), 7.90(\mathrm{ddd}, J=8.1,2.1,1.1 \mathrm{~Hz}, 1 \mathrm{H}), 7.64(\mathrm{t}, J=$ $8.1 \mathrm{~Hz}, 1 \mathrm{H}), 7.57$ (ddd, $J=8.1,2.0,1.0 \mathrm{~Hz}, 1 \mathrm{H}), 4.39$ (q, $J=$ $7.1 \mathrm{~Hz}, 2 \mathrm{H}), 1.34(\mathrm{t}, J=7.1 \mathrm{~Hz}, 3 \mathrm{H}) .{ }^{13} \mathrm{C}$ NMR (101 MHz, DMSO- $\left.\boldsymbol{d}_{6}\right) \delta 159.6(\mathrm{C}), 155.2$ (C), 144.9 (CH), 137.9 (C), $134.6(\mathrm{C}), 132.1(\mathrm{CH}), 128.9(\mathrm{CH}), 120.3(\mathrm{CH}), 119.1(\mathrm{CH})$, $61.9\left(\mathrm{CH}_{2}\right), 14.5\left(\mathrm{CH}_{3}\right)$. IR (neat): $3109.6(\mathrm{w}), 1719.9(\mathrm{~s})$, $1595.0(\mathrm{~m}), 1485.9(\mathrm{~m}), 1450.6(\mathrm{~s}), 1341.9(\mathrm{~m}), 1256.3(\mathrm{~s})$, 1198.1 (s), 1103.1 (s), 1079.9 (s), 1028.7 (s), 993.6 (s), 892.9 (s), $846.7(\mathrm{~m}), 792.0(\mathrm{~s}), 769.0(\mathrm{~s}), 667.4(\mathrm{~s}) \mathrm{cm}^{-1}$. LC-MS (ESI): $274.0(\mathrm{M}+\mathrm{Na})$; HRMS (ESI): calculated for $\mathrm{C}_{11} \mathrm{H}_{11} \mathrm{~N}_{3} \mathrm{O}_{2} \mathrm{Cl}$ 252.0540, found $252.0535(\mathrm{M}+\mathrm{H}, \Delta=-0.5 \mathrm{ppm})$.

Ethyl 1-(4-chlorophenyl))-1H-1,2,4-triazole-3-carboxylate, 7h. 67\%: Mp 136.5-137.0 ${ }^{\circ} \mathrm{C}$. Compound description: white crystalline solid. ${ }^{1} \mathbf{H}$ NMR (400 MHz, DMSO-d $\left.\mathbf{d}_{\mathbf{6}}\right) \quad \delta .48(\mathrm{~s}, 1 \mathrm{H})$, $7.95(\mathrm{~d}, J=8.9 \mathrm{~Hz}, 2 \mathrm{H}), 7.68(\mathrm{~d}, J=8.9 \mathrm{~Hz}, 2 \mathrm{H}), 4.38$ (q, $J=$ $7.1 \mathrm{~Hz}, 2 \mathrm{H}), 1.34(\mathrm{t}, J=7.1 \mathrm{~Hz}, 3 \mathrm{H}) .{ }^{13} \mathrm{C}$ NMR (101 MHz, DMSO- $\left.\boldsymbol{d}_{6}\right) \delta 159.6(\mathrm{C}), 155.2(\mathrm{C}), 144.7(\mathrm{CH}), 135.6(\mathrm{C})$, $133.4(\mathrm{C}), 130.3(2 \mathrm{CH}), 122.2(2 \mathrm{CH}), 61.9\left(\mathrm{CH}_{2}\right), 14.6\left(\mathrm{CH}_{3}\right)$. IR (neat): $3125.9(\mathrm{w}), 1725.3(\mathrm{~m}), 1487.3(\mathrm{~s}), 1450.4(\mathrm{~s})$, 1339.4 (m), 1257.5 (s), 1202.6 (s), 1074.8 (s), 1028.0 (m), 981.5 (s), $831.2(\mathrm{~s}), 668.4(\mathrm{~m}) \mathrm{cm}^{-1}$. LC-MS (ESI): $274.1(\mathrm{M}+\mathrm{Na})$; HRMS (ESI): calculated for $\mathrm{C}_{11} \mathrm{H}_{11} \mathrm{~N}_{3} \mathrm{O}_{2} \mathrm{Cl}$ 252.0540, found 252.0541 ( $\mathrm{M}+\mathrm{H}, \Delta=+0.1 \mathrm{ppm})$. CCDC 1039438.

Ethyl 7-chloro-5-nitropyrrolo[1,2-c]pyrimidine-3-carboxylate, 12a. $72 \%$, Mp $145{ }^{\circ} \mathrm{C}$ (decomposition). Compound description: brown solid. ${ }^{1} \mathbf{H}$ NMR (600 $\left.\mathbf{~ M H z , ~} \mathbf{C D C l}_{3}\right) \delta 9.06(\mathrm{~s}, 1 \mathrm{H})$, $8.96(\mathrm{~s}, 1 \mathrm{H}), 7.51(\mathrm{~s}, 1 \mathrm{H}), 4.50(\mathrm{q}, J=7.2 \mathrm{~Hz}, 2 \mathrm{H}), 1.45(\mathrm{t}, J=$ $7.2 \mathrm{~Hz}, 3 \mathrm{H}) .{ }^{13} \mathbf{C}$ NMR (151 MHz, $\left.\mathbf{C D C l}_{3}\right) \delta 163.3(\mathrm{C}), 138.6(\mathrm{C})$, $135.5(\mathrm{CH}), 129.0(\mathrm{C}), 127.9(\mathrm{C}), 115.5(\mathrm{CH}), 112.5(\mathrm{CH}), 111.5$ (C), $62.6\left(\mathrm{CH}_{2}\right), 14.3\left(\mathrm{CH}_{3}\right)$. IR (neat): $3132.5(\mathrm{w}), 1727.3(\mathrm{~s})$, $1617.9(\mathrm{w}), 1481.0(\mathrm{~s}), 1425.5(\mathrm{~m}), 1406.5(\mathrm{~m}), 1314.6(\mathrm{~s})$, $1221.6(\mathrm{~s}), 1127.7(\mathrm{~s}), 1101.3(\mathrm{~s}), 1010.2(\mathrm{~m}), 973.6(\mathrm{~m})$, $848.4(\mathrm{~m}), 783.7(\mathrm{~s}), 759.6(\mathrm{~m}) \mathrm{cm}^{-1}$. LC-MS (ESI): 270.1.0 $(\mathrm{M}+\mathrm{H})$; HRMS (ESI): calculated for $\mathrm{C}_{10} \mathrm{H}_{9} \mathrm{~N}_{3} \mathrm{O}_{4} \mathrm{Cl} 270.0282$, found 270.0287 ( $\mathrm{M}+\mathrm{H}, \Delta=1.9 \mathrm{ppm})$. CCDC 1039441.

Ethyl 5-bromo-7-chloropyrrolo[1,2-c]pyrimidine-3-carboxylate, 12b. $83 \%$, Mp 109.1-113.0 ${ }^{\circ} \mathrm{C}$. Compound description: Beige solid. ${ }^{1} \mathbf{H}$ NMR (400 $\left.\mathbf{~ M H z}, \mathbf{C D C l}_{3}\right) \delta 8.77(\mathrm{~d}, J=1.6 \mathrm{~Hz}$, $1 \mathrm{H}), 8.15(\mathrm{~d}, J=1.6 \mathrm{~Hz}, 1 \mathrm{H}), 6.91(\mathrm{~s}, 1 \mathrm{H}), 4.46(\mathrm{q}, J=7.2 \mathrm{~Hz})$, $1.44(\mathrm{t}, J=7.2 \mathrm{~Hz}, 3 \mathrm{H}) .{ }^{13} \mathrm{C}$ NMR (101 MHz, $\left.\mathbf{C D C l}_{3}\right) \delta 164.4(\mathrm{C})$, $134.8(\mathrm{CH}), 131.4(\mathrm{C}), 128.7(\mathrm{C}), 117.7(\mathrm{CH}), 115.6(\mathrm{CH}), 110.1$ (C), 92.5 (C), $61.9\left(\mathrm{CH}_{2}\right), 14.4\left(\mathrm{CH}_{3}\right)$. IR (neat): $1699.8(\mathrm{~s})$, $1524.7(\mathrm{~m}), 1445.7(\mathrm{~m}), 1422.2(\mathrm{~m}), 1368.0(\mathrm{~m}), 1288.4(\mathrm{~s})$, 1232.1 (s), $1086.4(\mathrm{~m}), 1019.8(\mathrm{~m}), 813.1$ (m), 776.5 (s), 711.1 (m), 593.5 (s) cm $\mathrm{cm}^{-1}$. LC-MS (ESI): $303.4(\mathrm{M}+\mathrm{H})$; HRMS (ESI): calculated for $\mathrm{C}_{10} \mathrm{H}_{9} \mathrm{~N}_{2} \mathrm{O}_{2} \mathrm{ClBr} 302.9536$, found 302.9541 $(\mathrm{M}+\mathrm{H}, \Delta=1.7 \mathrm{ppm})$.

Ethyl 5-chloro-7-bromopyrrolo[1,2-c]pyrimidine-3-carboxylate, 12c. $79 \%, \mathrm{Mp} 110{ }^{\circ} \mathrm{C}$ (decomposition). Compound description: brown solid. ${ }^{1} \mathbf{H}$ NMR (400 $\left.\mathbf{~ M H z , ~} \mathbf{C D C l}_{3}\right) \delta 8.75(\mathrm{~d}$, $J=1.2 \mathrm{~Hz}, 1 \mathrm{H}), 8.14(\mathrm{~d}, J=1.2 \mathrm{~Hz}, 1 \mathrm{H}), 6.91(\mathrm{~s}, 1 \mathrm{H}), 4.44(\mathrm{q}, J=$ $7.2 \mathrm{~Hz}, 2 \mathrm{H}), 1.42(\mathrm{t}, J=7.2 \mathrm{~Hz}, 3 \mathrm{H}) \cdot{ }^{13} \mathrm{C}$ NMR (101 MHz, $\left.\mathbf{C D C l}_{3}\right) \delta 164.4(\mathrm{C}), 136.0(\mathrm{CH}), 131.1(\mathrm{C}), 128.6(\mathrm{C}), 119.1(\mathrm{CH})$,
$114.6(\mathrm{CH}), 108.7$ (C), $94.4(\mathrm{C}), 61.9\left(\mathrm{CH}_{2}\right), 14.4\left(\mathrm{CH}_{3}\right)$. IR (neat): $1701.2(\mathrm{~s}), 1524.6(\mathrm{~m}), 1420.1(\mathrm{~m}), 1361.7(\mathrm{~m}), 1313.0$ (m), 1283.0 (s), 1243.8 (s), 1091.9 (m), 1017.4 (m), 821.5 (s), 774.8 (s), 711.5 (s), 594.5 (s) cm cm $^{-1}$ LC-MS (ESI): 324.9 (M + Na); HRMS (ESI): calculated for $\mathrm{C}_{10} \mathrm{H}_{8} \mathrm{~N}_{2} \mathrm{O}_{2} \mathrm{ClBrNa} 324.9355$, found $324.9358(\mathrm{M}+\mathrm{Na}, \Delta=0.9 \mathrm{ppm})$.

Ethyl 5,7-dinitropyrrolo[1,2-c]pyrimidine-3-carboxylate, 12d. $90 \%$, Mp 100.8-103.3 ${ }^{\circ} \mathrm{C}$. Compound description: yellowbrown solid. ${ }^{1} \mathbf{H}$ NMR (400 $\left.\mathbf{~ M H z , ~} \mathbf{C D C l}_{3}\right) \delta 10.37$ (d, $J=1.2 \mathrm{~Hz}$, $1 \mathrm{H}), 9.18$ (d, $J=1.2 \mathrm{~Hz}), 8.46(\mathrm{~s}, 1 \mathrm{H}), 4.55$ (q, $J=7.2 \mathrm{~Hz}, 2 \mathrm{H})$, $1.49(\mathrm{t}, J=7.2 \mathrm{~Hz}, 3 \mathrm{H}) .{ }^{13} \mathrm{C}$ NMR (101 MHz, $\left.\mathbf{C D C l}_{3}\right) \delta 162.4(\mathrm{C})$, 142.3 (C), 138.1 (CH), 131.7 (C), 129.5 (C), 127.6 (C), $115.8(\mathrm{CH}), 115.5(\mathrm{CH}), 63.2\left(\mathrm{CH}_{2}\right), 14.3\left(\mathrm{CH}_{3}\right)$. IR (neat): $1729.3(\mathrm{~s}), 1500.8(\mathrm{~m}), 1475.7(\mathrm{~m}), 1334.1(\mathrm{~s}), 1239.2(\mathrm{~s})$, $1139.2(\mathrm{~m}), 1005.6(\mathrm{~s}), 815.4(\mathrm{~m}), 784.7(\mathrm{~s}), 764.2(\mathrm{~s}), 735.8(\mathrm{~s})$, $611.0(\mathrm{~m}) \mathrm{cm}^{-1}$. LC-MS (ESI): $303.4(\mathrm{M}+\mathrm{Na}$ ); HRMS (ESI): calculated for $\mathrm{C}_{10} \mathrm{H}_{9} \mathrm{~N}_{4} \mathrm{O}_{6} 281.0522$, found $281.0510(\mathrm{M}+\mathrm{H}$, $\Delta=-4.3 \mathrm{ppm})$.

Ethyl 5,7-dibromopyrrolo[1,2-c]pyrimidine-3-carboxylate, 12e. $92 \%$, Mp $113.8-115.5{ }^{\circ} \mathrm{C}$. Compound description: brown solid. ${ }^{1} \mathbf{H}$ NMR (400 MHz, $\left.\mathbf{C D C l}_{3}\right) \delta 8.68(\mathrm{~d}, J=1.6 \mathrm{~Hz}, 1 \mathrm{H})$, $7.99(\mathrm{~d}, J=1.6 \mathrm{~Hz}, 1 \mathrm{H}), 6.88(\mathrm{~s}, 1 \mathrm{H}), 4.39(\mathrm{q}, J=7.2 \mathrm{~Hz}, 2 \mathrm{H})$, $1.37(\mathrm{t}, J=7.2 \mathrm{~Hz}, 3 \mathrm{H}) \cdot{ }^{13} \mathrm{C}$ NMR (101 MHz, $\left.\mathbf{C D C l}_{3}\right) \delta 164.3(\mathrm{C})$, $136.1(\mathrm{CH}), 131.5(\mathrm{C}), 130.2(\mathrm{C}), 121.1(\mathrm{CH}), 115.2(\mathrm{CH}), 95.1$ (C), $93.2(\mathrm{C}), 61.8\left(\mathrm{CH}_{2}\right), 14.4\left(\mathrm{CH}_{3}\right)$. IR (neat): $1700.7(\mathrm{~s})$, 1521.5 (w), 1416.9 (s), 1345.0 (s), 1281.7 (s), 1241.1 (s), 1016.2 (s), 823.4 (s), 775.1 (s), 710.9 (s), 593.4 (s) $\mathrm{cm}^{-1}$. LC-MS (ESI): $346.8(\mathrm{M}+\mathrm{H})$; HRMS (ESI): calculated for $\mathrm{C}_{10} \mathrm{H}_{9} \mathrm{~N}_{2} \mathrm{O}_{2} \mathrm{Br}_{2}$ 346.9031 , found 346.9015 ( $\mathrm{M}+\mathrm{H}, \Delta=-4.6 \mathrm{ppm})$.

Ethyl 5-bromo-7-(2,2,2-trifluoroacetyl)pyrrolo[1,2-c]pyrimidine-3-carboxylate, 12f. $73 \%$, Mp 106.8-108.3 ${ }^{\circ} \mathrm{C}$. Compound description: beige solid. ${ }^{\mathbf{1}} \mathbf{H}$ NMR (400 $\left.\mathbf{~ M H z}, \mathbf{C D C l}_{\mathbf{3}}\right) \delta 10.38$ (d, $1 \mathrm{H}, J=1.6 \mathrm{~Hz}), 8.38$ (d, $1 \mathrm{H}, J=1.6 \mathrm{~Hz}), 7.86(\mathrm{q}, 1 \mathrm{H}, J=2.0 \mathrm{~Hz})$, 4.51 (q, 2H, $J=7.2 \mathrm{~Hz}), 1.46(\mathrm{t}, 3 \mathrm{H}, J=7.2 \mathrm{~Hz}) \cdot{ }^{13} \mathbf{C}$ NMR (101 MHz, $\mathbf{C D C l}_{3}$ ) $\delta 169.4$ (q, $\left.J=37 \mathrm{~Hz}, \mathrm{C}\right), 163.4$ (C), 140.0 (CH), 139.3 (C), 137.9 (C), 129.0 (q, $J=4 \mathrm{~Hz}, \mathrm{CH}), 118.2$ (C), 119.5 (q, $\left.J=290 \mathrm{~Hz}, \mathrm{CF}_{3}\right), 115.1(\mathrm{CH}), 95.9(\mathrm{C}), 62.7\left(\mathrm{CH}_{2}\right), 14.3$ $\left(\mathrm{CH}_{3}\right) .{ }^{19} \mathbf{F}$ NMR (376 $\left.\mathbf{M H z}, \mathbf{C D C l}_{3}\right) \delta-71.71$ (s). IR (neat): $3086.2(\mathrm{w}), 1736.3(\mathrm{~m}), 1662.6(\mathrm{~m}), 1351.1(\mathrm{~m}), 1214.0(\mathrm{~m})$, $1155.6(\mathrm{~s}), 1098.0(\mathrm{~s}), 906.3(\mathrm{~m}), 851.2(\mathrm{~m}), 756.7(\mathrm{~m}), 657.6(\mathrm{~m})$ $\mathrm{cm}^{-1}$. LC-MS (ESI): 386.9 (M + Na); HRMS (ESI): calculated for $\mathrm{C}_{12} \mathrm{H}_{9} \mathrm{~N}_{2} \mathrm{O}_{3} \mathrm{BrF}_{3}$ 364.9749, found $364.9750(\mathrm{M}+\mathrm{H}, \Delta=$ 0.3 ppm). CCDC 1039439.

Ethyl 5-iodo-7-formylpyrrolo[1,2-c]pyrimidine-3-carboxylate, 12g. 77\%, Mp $205{ }^{\circ} \mathrm{C}$ (decomposition). Compound description: yellow solid. ${ }^{\mathbf{1}} \mathbf{H} \mathbf{~ N M R}\left(\mathbf{4 0 0} \mathbf{~ M H z}, \mathbf{C D C l}_{3}\right) \delta 10.23(\mathrm{~d}, J=1.2$ $\mathrm{Hz}, 1 \mathrm{H}), 9.86$ (s, 1H), 8.27 (d, $J=1.2 \mathrm{~Hz}, 1 \mathrm{H}), 7.75$ (s, 1H), 4.51 (q, $J=7.2 \mathrm{~Hz}, 2 \mathrm{H}), 1.47$ (t, $J=7.2 \mathrm{~Hz}, 3 \mathrm{H}) .{ }^{13} \mathrm{C}$ NMR (101 MHz, $\left.\mathbf{C D C l}_{3}\right) \delta 178.2(\mathrm{CHO}), 163.9(\mathrm{C}), 140.2(\mathrm{CH}), 138.6(\mathrm{C}), 138.1$ (C), $134.6(\mathrm{CH}), 126.3(\mathrm{CH}), 116.9(\mathrm{CH}), 62.5\left(\mathrm{CH}_{2}\right), 60.5(\mathrm{C})$, $14.4\left(\mathrm{CH}_{3}\right)$. IR (neat): $3100.3(\mathrm{w}), 2979.5(\mathrm{w}), 1717.2$ (s), 1642.2 (s), $1471.4(\mathrm{~m}), 1431.6$ (s), 1342.7 (s), 1268.3 (s), 1235.5 (s), 1139.2 (s), 1019.2 (s), 764.1 (s), 729.6 (s), 695.8 (m), $612.0(\mathrm{~m}) \mathrm{cm}^{-1}$. LC-MS (ESI): $366.9(\mathrm{M}+\mathrm{Na}$ ); HRMS (ESI): calculated for $\mathrm{C}_{11} \mathrm{H}_{9} \mathrm{~N}_{2} \mathrm{O}_{3} \mathrm{INa}$ 366.9556, found 366.9557 $(\mathrm{M}+\mathrm{Na}, \Delta=0.3 \mathrm{ppm})$. 
Ethyl 7-iodo-5-nitropyrrolo[1,2-c]pyrimidine-3-carboxylate, 12h. $41 \%$, Mp $150{ }^{\circ} \mathrm{C}$ (decomposition). Compound description: brown solid. ${ }^{\mathbf{1}} \mathbf{H}$ NMR (400 $\left.\mathbf{~ M H z , ~} \mathbf{C D C l}_{3}\right) \delta 9.05(\mathrm{~d}, J=1.4$ $\mathrm{Hz}, 1 \mathrm{H}), 8.89$ (d, $J=1.4 \mathrm{~Hz}, 1 \mathrm{H}), 7.79$ (s, 1H), 4.52 (q, $J=7.2$ $\mathrm{Hz}, 2 \mathrm{H}), 1.47$ (t, $J=7.2 \mathrm{~Hz}, 3 \mathrm{H}) .{ }^{13} \mathbf{C ~ N M R}\left(101 \mathbf{~ M H z}, \mathbf{C D C l}_{3}\right)$ $\delta 163.4$ (C), 140.0 (CH), 138.9 (C), 132.7 (C), 130.7 (C), 123.5 (CH), $115.1(\mathrm{CH}), 63.1(\mathrm{C}), 62.6\left(\mathrm{CH}_{2}\right), 14.3\left(\mathrm{CH}_{3}\right)$. IR (neat): 1699.6 (s), 1486.6 (m), 1406.2 (s), 1296.4 (s), 1276.6 (s), 1215.5 (s), 1012.2 (s), 779.6 (s), 756.3 (s), 598.1 (s) cm cm $^{-1}$ LC-MS (ESI): $361.9(\mathrm{M}+\mathrm{H})$; HRMS (ESI): calculated for $\mathrm{C}_{10} \mathrm{H}_{9} \mathrm{~N}_{3} \mathrm{O}_{4} \mathrm{I}$ 361.9638, found $361.9633(\mathrm{M}+\mathrm{H}, \Delta=-1.4 \mathrm{ppm})$.

Ethyl 5-iodo-7-nitropyrrolo[1,2-c]pyrimidine-3-carboxylate, 12i. $37 \%$, Mp $170{ }^{\circ} \mathrm{C}$ (decomposition). Compound description: bright yellow solid. ${ }^{1} \mathbf{H}$ NMR (400 $\left.\mathbf{~ M H z , ~} \mathbf{C D C l}_{3}\right) \delta 10.18(\mathrm{~d}, J=$ $1.2 \mathrm{~Hz}, 1 \mathrm{H}), 8.32$ (d, $J=1.2 \mathrm{~Hz}, 1 \mathrm{H}), 8.07(\mathrm{~s}, 1 \mathrm{H}), 4.55$ (q, $J=$ $7.2 \mathrm{~Hz}, 2 \mathrm{H}), 1.50(\mathrm{t}, J=7.2 \mathrm{~Hz}, 3 \mathrm{H}) .{ }^{13} \mathrm{C}$ NMR (101 MHz, $\left.\mathbf{C D C l}_{3}\right) \delta 163.4(\mathrm{C}), 138.4(\mathrm{CH}), 138.1$ (C), $137.0(\mathrm{C}), 132.4(\mathrm{C})$, $126.6(\mathrm{CH}), 117.1(\mathrm{CH}), 62.7\left(\mathrm{CH}_{2}\right), 60.9(\mathrm{C}), 14.3\left(\mathrm{CH}_{3}\right)$. IR (neat): $1712.2(\mathrm{~m}), 1505.4(\mathrm{~m}), 1436.4$ (s), 1381.0 (s), 1313.5 (s), 1282.7 (s), 1211.5 (s), $1020.0(\mathrm{~m}), 813.3(\mathrm{~m}), 722.6(\mathrm{~s}) \mathrm{cm}^{-1}$. LC-MS (ESI): $361.9(\mathrm{M}+\mathrm{H})$; HRMS (ESI): calculated for $\mathrm{C}_{10} \mathrm{H}_{9} \mathrm{~N}_{3} \mathrm{O}_{4} \mathrm{I}$ 361.9638, found $361.9644(\mathrm{M}+\mathrm{H}, \Delta=1.7 \mathrm{ppm})$. CCDC 1039440.

\section{Acknowledgements}

We gratefully acknowledge financial support through the Royal Society (M.B. and I.R.B.) and MEC \& MINECO for a FPU fellowship (A.M.R.G.). Furthermore we are very grateful to Dr D. S. Yufid and Dr A. S. Batsanov (Department of Chemistry, Durham University) for solving several X-ray crystal structures.

\section{Notes and references}

1 (a) J. J. Li, Heterocyclic Chemistry in Drug Discovery, Wiley, 2013. ISBN: 978-1-118-14890-7; (b) R. B. Silverman, The Organic Chemistry of Drug Design and Drug Action, Elsevier Academic Press, Burlington, MA, 2004; (c) H. Wild, D. Heimbach and C. Huwe, Angew. Chem., Int. Ed., 2011, 50, 7452 .

2 (a) M. Baumann, I. R. Baxendale, S. V. Ley and N. Nikbin, Beilstein J. Org. Chem., 2011, 7, 442; (b) M. Baumann and I. R. Baxendale, Beilstein J. Org. Chem., 2013, 9, 2265; (c) E. Vitaku, D. T. Smith and J. T. Njardarson, J. Med. Chem., 2014, 57, 10257.

3 (a) L. Malet-Sanz and F. Susanne, J. Med. Chem., 2012, 55, 4062; (b) M. Baumann, I. R. Baxendale and S. V. Ley, Mol. Diversity, 2011, 15, 613; (c) R. L. Hartman, J. P. McMullen and K. F. Jensen, Angew. Chem., Int. Ed., 2011, 50, 7502; (d) C. Wiles and P. Watts, Green Chem., 2012, 14, 38; (e) V. Hessel, B. Cortese and M. H. J. M. de Croon, Chem. Eng. Sci., 2011, 66, 1426; $(f)$ J. Yoshida, H. Kim and A. Nagaki, ChemSusChem, 2010, 4, 331; (g) M. D. Hopkin,
I. R. Baxendale and S. V. Ley, Org. Biomol. Chem., 2013, 11, 1822 .

4 (a) I. R. Baxendale, L. Brocken and C. J. Mallia, Green Process Synth., 2013, 2, 211; (b) I. R. Baxendale, J. Chem. Technol. Biotechnol., 2013, 88, 4, 519; (c) J. Wegner, S. Ceylan and A. Kirschning, Adv. Synth. Catal., 2012, 354, 17; (d) J. C. Pastre, D. L. Browne, M. O'Brien and S. V. Ley, Org. Process Res. Dev., 2013, 17, 1183; (e) M. A. Kabeshov, B. Musio, P. R. D. Murray, D. L. Browne and S. V. Ley, Org. Lett., 2014, 16, 4618; (f) J. Wegner, S. Ceylan and A. Kirschning, Org. Biomol. Chem., 2012, 10, 7721; (g) P. R. D. Murray, D. L. Browne, J. C. Pastre, C. Butters, D. Guthrie and S. V. Ley, Org. Process Res. Dev., 2013, 17, 1192.

5 (a) M. O'Brien, I. R. Baxendale and S. V. Ley, Org. Lett., 2010, 12, 1596; (b) C. Battilochio, I. R. Baxendale, M. Biava, M. O. Kitching and S. V. Ley, Org. Process Res. Dev., 2012, 16, 798; (c) M. Irfan, T. N. Glasnov and C. O. Kappe, Org. Lett., 2011, 13, 984.

6 (a) C. J. Smith, C. D. Smith, N. Nikbin, S. V. Ley and I. R. Baxendale, Org. Biomol. Chem., 2011, 9, 1927; (b) H. R. Sahoo, J. G. Kralj and K. F. Jensen, Angew. Chem., Int. Ed., 2007, 46, 5704; (c) L. Kupracz, J. Hartwig, J. Wegner, S. Ceylan and A. Kirschning, Beilstein J. Org. Chem., 2011, 7, 1441; (d) M. Baumann, I. R. Baxendale, S. V. Ley, N. Nikbin, C. D. Smith and J. P. Tierney, Org. Biomol. Chem., 2008, 6, 1577; (e) C. J. Smith, N. Nikbin, S. V. Ley, H. Lange and I. R. Baxendale, Org. Biomol. Chem., 2011, 9, 1938; (f) P. B. Palde and T. F. Jamison, Angew. Chem., Int. Ed., 2011, 50, 3525; ( $g$ ) I. R. Baxendale, S. V. Ley, A. C. Mansfield and C. D. Smith, Angew. Chem., Int. Ed., 2009, 48, 4017; (h) F. R. Bou-Hamdan, F. Lévesque, A. G. O'Brien and P. H. Seeberger, Beilstein J. Org. Chem., 2011, 7, 1124; (i) C. D. Smith, I. R. Baxendale, S. Lanners, J. J. Hayward, S. C. Smith and S. V. Ley, Org. Biomol. Chem., 2007, 5, 1559; (j) C. J. Smith, N. Nikbin, C. D. Smith, S. V. Ley and I. R. Baxendale, Org. Biomol. Chem., 2011, 9, 1927; (k) M. M. E. Delville, P. J. Nieuwland, P. Janssen, K. Koch, J. C. M. van Hest and F. P. J. T. Rutjes, Chem. Eng. J., 2011, 167, 556.

7 (a) D. X. Hu, M. O’Brien and S. V. Ley, Org. Lett., 2012, 14, 4246; (b) L. Malet-Sanz, J. Madrzak, S. V. Ley and I. R. Baxendale, Org. Biomol. Chem., 2010, 8, 3312.

8 (a) C. McPake, C. B. Murray and G. Sandford, Tetrahedron Lett., 2009, 50, 1674; (b) C. McPake and G. Sandford, Org. Process Res. Dev., 2012, 16, 844; (c) J. R. Breen, G. Sandford, D. S. Yufit, J. A. K. Howard, J. Fray and B. Patel, Beilstein J. Org. Chem., 2011, 7, 1048.

9 (a) D. L. Browne, M. Baumann, B. H. Harji, I. R. Baxendale and S. V. Ley, Org. Lett., 2011, 13, 3312; (b) J. A. Newby, D. W. Blaylock, P. M. Witt, J. C. Pastre, M. K. Zacharova, S. V. Ley and D. L. Browne, Org. Process Res. Dev., 2014, 18, 1211; (c) A. Nagaki, A. Kenmoku, Y. Moriwaki, A. Hayashi and J. Yoshida, Angew. Chem., Int. Ed., 2010, 49, 7543; (d) A. Nagaki, E. Takizawa and J. Yoshida, Chem. - Eur. J., 2010, 16, 14149. 
10 (a) J. Hartwig, S. Ceylan, L. Kupracz, L. Coutable and A. Kirschning, Angew. Chem., Int. Ed., 2013, 52, 9813; (b) J. Hartwig, L. Kupracz and A. Kirschning, Chem. Lett., 2012, 41, 562; (c) B. Reichart and C. O. Kappe, Tetrahedron Lett., 2012, 53, 952; (d) J. Yoshida, Flash Chemistry: Fast Organic Synthesis in Microsystems, John Wiley \& Sons, Chichester, UK, 2008.

11 (a) K. Matsumoto and M. Suzuki, Ethyl Isocyanoacetate; Encyclopedia of Reagents for Organic Synthesis, 2001;

(b) M. Suginome and Y. Ito, Sci. Synth., 2004, 19, 445;

(c) S. Kotha and S. Halder, Synlett, 2010, 337;

(d) M. Baumann, I. R. Baxendale, S. V. Ley, C. D. Smith and G. K. Tranmer, Org. Lett., 2006, 8, 5231.

$12 \mathrm{~N}$-formylglycine is commercially available (CAS 3154-51-6).

13 S. Fuse, N. Tanabe and T. Takahashi, Chem. Commun., 2011, 47, 12661.

14 K. Matsumoto, M. Suzuki, M. Tomie, N. Yoneda and M. Miyoshi, Synthesis, 1975, 609.

15 D. L. Browne, I. R. Baxendale and S. V. Ley, Tetrahedron, 2011, 67, 10296-10303.

16 M. Zibinsky and V. V. Fokin, Org. Lett., 2011, 13, 4870.

17 R. Romagnoli, P. G. Baraldi, O. Cruz-Lopez, C. Lopez Cara, M. D. Carrion, A. Brancale, E. Hamel, L. Chen, R. Bortolozzi, G. Basso and G. Viola, J. Med. Chem., 2010, 53, 4248.

18 For instance WO 2003070732; WO 2004039366; WO 2004064836 ; WO 2004052461.

19 (a) J. M. Minguez, J. J. Vaquero, J. L. García-Navio and J. Alvarez-Builla, Tetrahedron Lett., 1996, 37, 4263; (b) J. M. Minguez, J. J. Vaquero, J. Alvarez and O. Catano, J. Org. Chem., 1999, 64, 7788.

20 K. A. Peterson, B. C. Shepler, D. Figgen and H. Stoll, J. Phys. Chem. A, 2006, 110, 13877.

21 K. A. Peterson, D. Figgen, E. Goll, H. Stoll and M. Dolg, J. Chem. Phys., 2003, 119, 11113.

22 (a) Y. Zhao and D. G. Truhlar, Acc. Chem. Res., 2008, 41, 157; (b) Y. Zhao and D. G. Truhlar, Theor. Chem. Acc., 2007, $120,215$.
23 M. J. Frisch, G. W. Trucks, H. B. Schlegel, G. E. Scuseria, M. A. Robb, J. R. Cheeseman, G. Scalmani, V. Barone, B. Mennucci, G. A. Petersson, H. Nakatsuji, M. Caricato, X. Li, H. P. Hratchian, A. F. Izmaylov, J. Bloino, G. Zheng, J. L. Sonnenberg, M. Hada, M. Ehara, K. Toyota, R. Fukuda, J. Hasegawa, M. Ishida, T. Nakajima, Y. Honda, O. Kitao, H. Nakai, T. Vreven, J. A. Montgomery Jr., J. E. Peralta, F. Ogliaro, M. J. Bearpark, J. J. Heyd, E. N. Brothers, K. N. Kudin, V. N. Staroverov, R. Kobayashi, J. Normand, K. Raghavachari, A. P. Rendell, J. C. Burant, S. S. Iyengar, J. Tomasi, M. Cossi, N. Rega, N. J. Millam, M. Klene, J. E. Knox, J. B. Cross, V. Bakken, C. Adamo, J. Jaramillo, R. Gomperts, R. E. Stratmann, O. Yazyev, A. J. Austin, R. Cammi, C. Pomelli, J. W. Ochterski, R. L. Martin, K. Morokuma, V. G. Zakrzewski, G. A. Voth, P. Salvador, J. J. Dannenberg, S. Dapprich, A. D. Daniels, Ö. Farkas, J. B. Foresman, J. V. Ortiz, J. Cioslowski and D. J. Fox, GAUSSIAN 09 (Revision D.01), Gaussian Inc., Wallingford CT, 2009, 2009.

24 (a) S. Miertuš, E. Scrocco and J. Tomasi, Chem. Phys., 1981, 55, 117; (b) J. Tomasi, R. Cammi, B. Mennucci, C. Cappelli and S. Corni, Phys. Chem. Chem. Phys., 2002, 4, 5697; (c) J. Tomasi, B. Mennucci and R. Cammi, Chem. Rev., 2005, 105, 2999.

25 (a) M. Vicinius Nora de Souza, Curr. Org. Chem., 2007, 11, 637; (b) M. Schnürch, M. Spina, A. Farooq Khan, M. D. Mihovilovic and P. Stanetty, Chem. Soc. Rev., 2007, 36, 1046; (c) M. Schnürch, Recent Progress on the Halogen Dance Reaction on Heterocycles, in Halogenated Heterocycles, Topics in Heterocyclic Chemistry, Springer, 2012, vol. 27, pp. 185-218.

26 G. M. Sheldrick, Acta Crystallogr., Sect. A: Fundam. Crystallogr., 2008, 64, 112-122.

27 O. V. Dolomanov, L. J. Bourhis, R. J. Gildea, J. A. K. Howard and H. Puschmann, J. Appl. Crystallogr., 2009, 42, 339-341. 